\title{
Fused nucleoids resegregate faster than cell elongation in Escherichia coli pbpB(Ts) filaments after release from chloramphenicol inhibition
}

\author{
J. M. L. M. Van Helvoort, † P. G. Huls, N. O. E. Vischer and C. L. Woldringh
}

Author for correspondence: C.L. Woldringh. Tel: +3120525 6219. Fax: +31 205256271. e-mail: woldringh@bio.uva.nl

Institute for Molecular Cell Biology, BioCentrum Amsterdam, University of Amsterdam, Kruislaan 316 , 1098 SM Amsterdam, The Netherlands

\begin{abstract}
The course of nucleoid movement during and upon release from protein synthesis inhibition by chloramphenicol in filaments of Escherichia coli pbpB(Ts) was analysed. Cells were grown at $42{ }^{\circ} \mathrm{C}$ in glucose minimal medium for two mass doublings and were treated with chloramphenicol to generate fusion (coalescence) of the nucleoids. Upon release from protein synthesis inhibition, the large distance between the border of the fused nucleoids and the cell poles immediately decreased, before full recovery of the rates of mass growth and length increase at $30^{\circ} \mathrm{C}$. This indicates that nucleoids can reoccupy the DNA-free cell ends independently of cell elongation. During filamentation at $42{ }^{\circ} \mathrm{C}$, the pbpB cells established initial constrictions at midcell and at onequarter and three-quarter positions. Nevertheless, divisions only started 75 min after chloramphenicol removal at $30^{\circ} \mathrm{C}$, when most nucleoids had moved back into the vacated cell ends. No 'guillotine-like' constrictions at the site of the nucleoids occurred. This suggests that segregating nucleoids postpone division recovery at previously established sites. The results are discussed in the light of a working model for transcription/translationmediated chromosome segregation and nucleoid occlusion of cell division.
\end{abstract}

Keywords: Escherichia coli filaments, chloramphenicol treatment, nucleoid fusion, resegregation, cell division

\section{INTRODUCTION}

Although bacteria are too small to contain a structure like the eukaryotic mitotic spindle, they still have to separate replicated DNA daughter strands and to segregate their nucleoids before division. During this process of partitioning or segregation, bacterial nucleoids have been proposed to move abruptly after replication from midcell to one-quarter and threequarter positions (see Donachie, 1993; Hiraga, 1993 for reviews). Such movement can be considered as an indication for a 'mitosis-like mechanism' in Escherichia coli (Begg \& Donachie, 1991; Wheeler \& Shapiro, 1997). However, the abruptness can be ascribed to the use of chloramphenicol for enhancing the visibility of

†Present address: Department of Cell Biology and Immunology, Faculty of Medicine, Free University Amsterdam, Van der Boechorststraat 7, 1081 BT Amsterdam, The Netherlands.

Abbreviation: DAPI, 4',6-diamidino-2-phenylindole dihydrochloride hydrate. nucleoid positions (Van Helvoort et al., 1994). When nucleoids are visualized in untreated, exponentially growing cells, either living or after fixation, it appears that the distance between the nucleoid outer border and the cell pole remains constant throughout the cell cycle (Van Helvoort et al., 1994). According to our view, this indicates that nucleoids as a whole move gradually, along with DNA replication and cell elongation, and that the impression of an abrupt movement is only obtained when measuring the centre of nucleoids, especially in the case of the rounded nucleoids in chloramphenicol-treated cells.

The gradual movement of the nucleoid does not stop when DNA synthesis is inhibited: in SOS-filaments obtained by shifting the quick-stop DNA replication mutant E. coli dnaX (Ts) to $42^{\circ} \mathrm{C}$, segregation of nonreplicating nucleoids has been shown to continue as the nucleoid is pulled apart into small domains extending along the length and the periphery of the filament. The filaments are obtained by induction of the division 
inhibitor SfiA (Jaffé et al., 1986). Subsequent treatment with chloramphenicol caused the domains to contract again into one or two spherical nucleoids (Woldringh et al., 1994). Based on these observations, it has been proposed that the driving force for chromosome movement is provided by the process of protein synthesis and, more specifically, by co-transcriptional and co-translational translocation of membrane proteins (Woldringh et al., 1995a; see also Norris, 1995).

In spite of the continued movement of the nonreplicating nucleoids in $E$. coli $d n a X(T s)$ cells grown at $42^{\circ} \mathrm{C}$, large DNA-free cell ends developed in the SOSfilaments (Mulder \& Woldringh, 1989; see also Begg \& Donachie, 1991). Upon resumption of DNA synthesis at the permissive temperature, the nucleoid domains appeared not to be able to occupy the vacant cell ends. Instead, the nucleoids remained in place and increased in size by renewed DNA replication. The filaments recovered to normal-sized cells by first pinching off the DNA-free cell ends (Mulder \& Woldringh, 1989). Long, DNA-free cell ends are also produced when filaments of cell division mutants such as $E$. coli $p b p B$ or $f t s Z$ are treated with chloramphenicol (Van Helvoort et al., 1996), causing the coalescence or fusion of up to four segregated nucleoids into compact DNA regions. Since filaments recovering from induction of the SOS system produced DNA-less cells (Mulder \& Woldringh, 1989), we wondered whether filaments with fused nucleoids recovering from growth inhibition would also produce DNA-less cells, or whether they would segregate their nucleoids a second time. In the latter case, it would be of interest to determine whether the resegregating nucleoids return to their previously occupied positions before resumption of cell division.

In the present work we show that fused nucleoids are indeed able to gradually reoccupy the vacated cell ends and that cell division is largely postponed until resegregation has taken place. In addition, we show that nucleoid fusion can also be obtained by inhibition of RNA synthesis and by amino acid starvation.

\section{METHODS}

Bacterial strains. An isogenic derivative of $E$. coli K-12 strain MC4100 [F $\mathrm{F}^{-}$araD139 $\Delta$ (argF-lac)U169 deoC1 flbB5301 lysA $p t s F 25$ rbsR relA1 rpsL150] was used that carries the $p b p B 2158(T s)$ mutation (laboratory strain LMC510; Taschner et al., 1988).

Media and growth measurements. Cell cultures were grown in glucose-minimal medium containing $\left(\mathrm{l}^{-1}\right)$ : $6.33 \mathrm{~g}$ $\mathrm{K}_{2} \mathrm{HPO}_{4} .3 \mathrm{H}_{2} \mathrm{O}, \quad 2.95 \mathrm{~g} \quad \mathrm{KH}_{2} \mathrm{PO}_{4}, \quad 1.05 \mathrm{~g} \quad\left(\mathrm{NH}_{4}\right)_{2} \mathrm{SO}_{4}$, $0.1 \mathrm{~g} \quad \mathrm{MgSO}_{4} .7 \mathrm{H}_{2} \mathrm{O}, \quad 0.3 \mathrm{mg} \quad \mathrm{FeSO}_{4} .7 \mathrm{H}_{2} \mathrm{O}, \quad 7.1 \mathrm{mg}$ $\mathrm{Ca}\left(\mathrm{NO}_{3}\right)_{2}, 4 \mathrm{H}_{2} \mathrm{O}$ and $5 \mathrm{~g}$ glucose, supplemented with $50 \mu \mathrm{g}$ lysine ml $\mathrm{ml}^{-1}$ and $\mathrm{NaCl}$ to obtain an osmolarity of 300 mosM (Micro-Osmometer; Advanced Instruments). Mass growth was monitored by measuring the $\mathrm{OD}_{450}$ with a Gilford microsample spectrophotometer and cell numbers were measured with an electronic particle counter $(30 \mu \mathrm{m}$ orifice diameter).

To facilitate the analysis of nucleoid resegregation, the cells were synchronized by centrifugal elutriation (see below). The small cells were incubated at $42{ }^{\circ} \mathrm{C}$ for two mass doublings, before chloramphenicol (Boehringer Mannheim) was added to a final concentration of $200 \mu \mathrm{g} \mathrm{ml}^{-1}$. After $70 \mathrm{~min}$ in the presence of chloramphenicol at $42^{\circ} \mathrm{C}$, the cells were removed from the medium by filtration through a pre-wetted $0.22 \mu \mathrm{m}$ type GSWP Millipore filter. The cells were washed with 3 vols medium without chloramphenicol, prewarmed to $42^{\circ} \mathrm{C}$. The whole procedure was carried out in a $42{ }^{\circ} \mathrm{C}$ cabinet to prevent initiation of constriction. The filter was added to prewarmed medium without chloramphenicol at $30^{\circ} \mathrm{C}$ to restart growth and to allow cell division. The cells were easily washed from the filter. Samples for fluorescence microscopy were taken at appropriate intervals during the whole procedure after synchronization and were fixed in $0.1 \% \mathrm{OsO}_{4}$, final concentration.

To test the effect of different inhibitors of protein synthesis, exponentially growing cells were shifted to the restrictive temperature of $42^{\circ} \mathrm{C}$ and grown for two mass doublings before protein synthesis was inhibited, also at $42^{\circ} \mathrm{C}$, with $200 \mu \mathrm{g}$ chloramphenicol $\mathrm{ml}^{-1}$ or $100 \mu \mathrm{g}$ rifampicin $\mathrm{ml}^{-1}$ (Calbiochem). For amino acid starvation, lysine was removed by filtration as described above.

Synchronization by centrifugal elutriation. The procedure for centrifugal elutriation of $E$. coli cells was carried out as previously described for yeast cells (Woldringh et al., 1995b). Cells were grown exponentially in one l culture medium. At an $\mathrm{OD}_{450}$ of $0 \cdot 15$, the cell suspension was centrifuged at $4{ }^{\circ} \mathrm{C}$ and the cells were resuspended in $5 \mathrm{ml}$ culture medium. This suspension was loaded into a $5 \mathrm{ml}$ elutriation chamber (rotor JE-6B; Beckman Instruments) and equilibrated for $40 \mathrm{~min}$ at $4{ }^{\circ} \mathrm{C}, 5000$ r.p.m. at a flow rate of $2 \mathrm{ml} \mathrm{min}^{-1}$ using culture medium. Small cells were collected at a flow rate of $2.8 \mathrm{ml}$ $\mathrm{min}^{-1}$ and kept at $4{ }^{\circ} \mathrm{C}$ until $200 \mathrm{ml}$ cell suspension was obtained. The cell suspension was centrifuged and resuspended in $100 \mathrm{ml}$ prewarmed culture medium at $42{ }^{\circ} \mathrm{C}$ to start the experiment. The coefficient of variation of cell length (Cv) at the start of the experiment was $19 \%$ due to the presence of a few longer cells with two nucleoids (see Table 1).

Microscopical methods and image cytometry. Nucleoids in cells fixed with $0.1 \% \mathrm{OsO}_{4}$ were stained with $0 \cdot 2 \mu \mathrm{g}$ DAPI $\mathrm{ml}^{-1}$ (4',6-diamidino-2-phenylindole dihydrochloride hydrate; final concentration) for at least $1 \mathrm{~h}$. The cells were immobilized on object slides coated with a dried $2 \%$ agarose layer. The preparations were illuminated at $330-380 \mathrm{~nm}$. Images were taken with a Grundig FA851 charged-coupled-device (CCD) camera mounted on an Olympus $\mathrm{BH}-2$ fluorescence microscope equipped with an oil immersion lens, a $5 \times$ photo-ocular and an emission filter of $420 \mathrm{~nm}$. Length and diameter of cells and filaments, length and number of nucleoids, and the position and number of constriction sites were measured using the Object-Image version (Vischer et al., 1994) of the NIHimage software.

\section{RESULTS}

\section{Nucleoid fusion}

To facilitate analysis of the course of nucleoid fusion and movement in filaments, we started our experiments with a synchronized population of $E$. coli cells grown in glucose minimal medium (doubling time about $80 \mathrm{~min}$ ). The small cells (Fig. 1a), selected from the elutriation chamber, presumably represented newborn cells. They contained a single nucleoid region as visualized by fluorescence microscopy. As a measure of nucleoid size, 

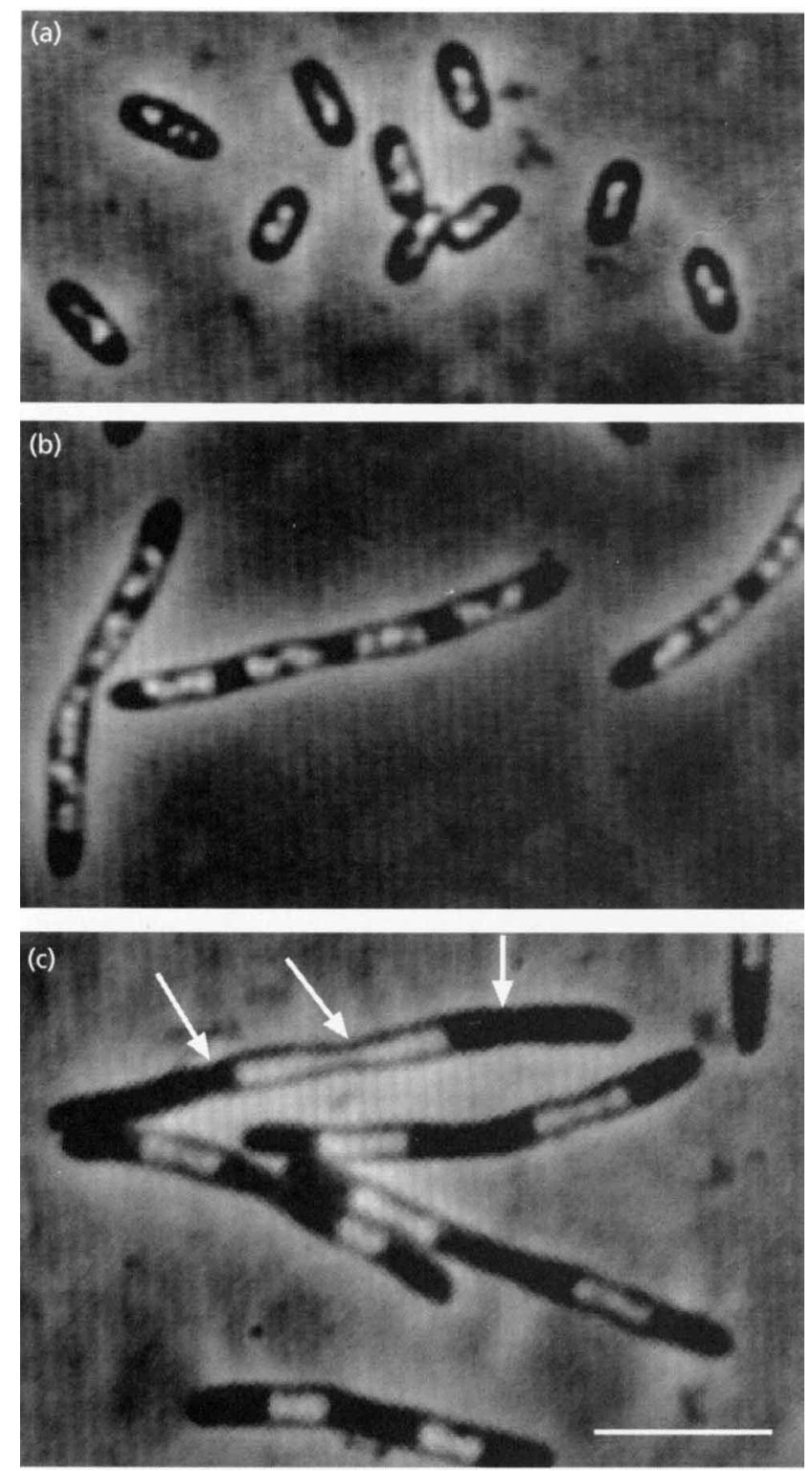

Fig. 1. Synchronized $E$. coli $p b p B$ filaments stained with DAPI and photographed by combined phase-contrast and fluorescence microscopy. (a) Small cells selected from the elutriation chamber and used for the growth experiment shown in Fig. 2(b). (b) Filaments obtained after growth of synchronized cells at $42{ }^{\circ} \mathrm{C}$ for two mass doublings (arrow 1 , Fig. 2c). (c) Filaments treated for $70 \mathrm{~min}$ with $200 \mu \mathrm{g}$ chloramphenicol ml-1 at $42{ }^{\circ} \mathrm{C}$ (arrow 2, Fig. 2c). Arrows indicate initiated but unfinished constrictions. Note the large DNA-less cell ends (dark areas). Bar, $5 \mu \mathrm{m}$.

the lengths of the nucleoid regions were determined $\left(L_{\mathrm{n}}\right.$ in Table 1). Preliminary measurements of the relative amount of DNA per nucleoid region by image cytometry, and comparison with the nucleoids in slowgrowing $E$. coli $\mathrm{B} / \mathrm{rH} 266$ cells, revealed that the nucleoid regions in the newborn cells shown in Fig. 1(a), with a mean length $\left(L_{\mathrm{n}}\right)$ of $1.26 \mu \mathrm{m}$, represented on average 1.8 chromosome equivalents, whereas in stationary-phase cells, nucleoids with either one or two chromosome

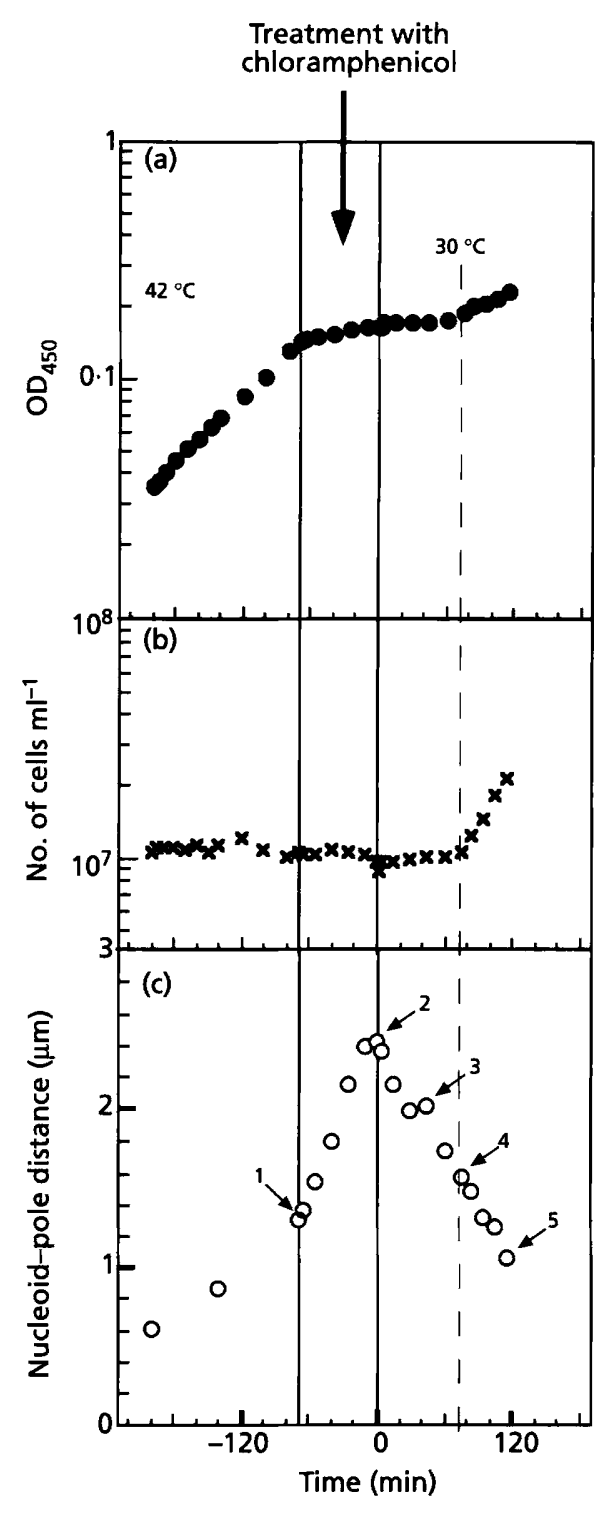

Fig. 2. Growth of synchronized cells before, during and after chloramphenicol treatment. Cells were grown at $42{ }^{\circ} \mathrm{C}$ until $-70 \mathrm{~min}$, treated with chloramphenicol until time 0 and released from protein synthesis inhibition at $30^{\circ} \mathrm{C}$ at time 0 . (a) Mass increase, measured as optical density of the synchronized pbpB filaments. (b) Cell number as determined with an electronic particle counter. (c) Distances between the outer borders of the most distal nucleoids and the cell poles. A minimum of 100 filaments per time point were measured. Arrows in (c) refer to the different panels in Figs 1 and 3 and to measurements presented in Table 1 . Note the increase and subsequent decrease in nucleoid-pole distances.

equivalents were found (to be reported elsewhere). This is reminiscent of the flow cytometric observations of Ảkerlund et al. (1995), who found that in stationaryphase cells, most nucleoids contained two chromosome equivalents.

Although the elutriation was performed at $4{ }^{\circ} \mathrm{C}$, the newborn cells immediately started growth when suspended in medium at $42{ }^{\circ} \mathrm{C}$ (Fig. 2a). While cell division 
Table 1. Length of $E$. coli $p b p B$ filaments or of newborn cells and their nucleoids, during chloramphenicol treatment and after recovery of growth and division

\begin{tabular}{|c|c|c|c|c|c|c|}
\hline Cell type & $\begin{array}{l}\text { Time (min) (see } \\
\text { arrows in Fig. } 2 \mathrm{c} \text { ) }\end{array}$ & $\begin{array}{l}\text { No. of cells } \\
\text { scored }\end{array}$ & $\begin{array}{c}L(\mathrm{CV})^{*} \\
(\mu \mathrm{m})\end{array}$ & $\begin{array}{c}L_{\mathrm{n}}(\mathrm{CV})^{*} \\
(\mu \mathrm{m})\end{array}$ & $\begin{array}{l}\text { Nucleoid } \\
\text { regions } \\
\text { per cell } \downarrow\end{array}$ & $\begin{array}{c}\text { DNA-less } \\
\text { cells } \\
\text { (\% of total } \\
\text { proportion) } \neq\end{array}$ \\
\hline Synchronized cells & -190 & 150 & $2 \cdot 62(19)$ & $1 \cdot 26(23)$ & $1 \cdot 1$ & 0 \\
\hline Filaments & -70 (arrow 1) & 100 & $10 \cdot 28(17)$ & $1.64(44)$ & 3.8 & 0 \\
\hline $\begin{array}{l}\text { Filaments treated with } \\
\text { chloramphenicol }\end{array}$ & 0 (arrow 2$)$ & 100 & $12 \cdot 83(23) \mathbb{S}$ & $2 \cdot 47(46)$ & $1 \cdot 9$ & 0 \\
\hline $\begin{array}{l}\text { Filaments recovering } \\
\text { from inhibition }\end{array}$ & 75 (arrow 4) & 100 & $11.90(27)$ & $2 \cdot 22(79)$ & $3 \cdot 2$ & 0 \\
\hline Newborn cells\| & 95 & 149 & $3 \cdot 49(24)$ & $1 \cdot 16(52)$ & $1 \cdot 2$ & 9 \\
\hline Newborn cells\| & 105 & 66 & $3.76(26)$ & $1 \cdot 17(65)$ & $1 \cdot 1$ & 20 \\
\hline Newborn cells $\|$ & 115 (arrow 5) & 138 & $3 \cdot 56(15)$ & $1.27(23)$ & 0.8 & 22 \\
\hline $\begin{array}{l}\text { Stationary phase } \\
\text { cells }\end{array}$ & $16 \mathrm{~h}$ & 150 & $2.97(53)$ & $1.37(71)$ & $1 \cdot 1$ & $<1$ \\
\hline
\end{tabular}

* $L$, mean cell length; $L_{\mathrm{n}}$, mean length of nucleoids measured along length axis of cell; $\mathrm{cv}$, coefficient of variation.

†A nucleoid region is defined as a separate, DAPI-stained entity. Preliminary image cytometric estimation of the relative amount of DNA revealed that the nucleoid regions in newborn cells represent on average 1.8 chromosome equivalents (to be reported elsewhere).

$\ddagger$ Populations of 100 cells or filaments were scored after DAPI staining.

\After filamenting for two mass doublings at $42^{\circ} \mathrm{C}$, cell elongation continued from 10.28 to $12.83 \mu \mathrm{m}$ during chloramphenicol treatment.

\| Small cells and deep constrictions at the end of filaments (see Fig. 3c) were measured as newborn cells.

was inhibited (Fig. 2b), growth for two mass doublings produced short filaments that on average had four separate nucleoid regions (Fig. 1b), 1.64 $\mu \mathrm{m}$ long (Table 1). Subsequently, the synchronized filaments were treated with $200 \mathrm{mg}$ chloramphenicol ml $\mathrm{m}^{-1}$ at $42^{\circ} \mathrm{C}$ for $70 \mathrm{~min}$, which caused fusion of the nucleoids (Fig. 1c), as described previously (Van Helvoort et al., 1996). During the chloramphenicol treatment, a slight increase in cell mass (Fig. 2a) and an increase in cell length from $10 \cdot 3$ to $12.8 \mu \mathrm{m}$ (Table 1 ) was observed. To evaluate movement of nucleoids, the distances between the outer border of the external nucleoid region and the cell poles were plotted as a function of time (Fig. 2c). It can be seen from Fig. 2(c) that growth at $42^{\circ} \mathrm{C}$ caused an increase of the nucleoid-pole distance (from 0.6 to $1.3 \mu \mathrm{m}$ ), suggesting some retardation in DNA segregation during filamentation. During the chloramphenicol treatment, nucleoid-pole distances increased to about $2.5 \mu \mathrm{m}$. Within 5 min of the start of chloramphenicol treatment, the number of separate nucleoid regions per cell dropped from a mean of 3.8 to a mean of 2.8 (result not shown), decreasing further to a mean of 1.9 elongated nucleoids per cell after $70 \mathrm{~min}$ of treatment $\left(L_{\mathrm{n}} 2.47 \mu \mathrm{m}\right.$; Table 1$)$. The initial drop in number coincides with only a gradual increase in the nucleoid-pole distance, as shown in Fig. 2 (c), suggesting that individual nucleoids first fuse before retracting from the cell poles. Compared with the nucleoids in growing filaments (Fig. 1b), the fused nucleoids after $70 \mathrm{~min}$ of chloramphenicol treatment (Fig. 1c) have a smoother shape and a larger diameter. In part, this may be ascribed to an increased amount of DNA as a result of run-out DNA synthesis during the chloramphenicol treatment (Bremer \& Churchward, 1977).

\section{Nucleoid resegregation}

After removal of the chloramphenicol by filtration, resegregation of nucleoids was observed while keeping the cells at restrictive temperature (results not shown). In the experiments described below, the filaments were allowed to resume growth and division at the permissive temperature. Fig. 2(a) shows that mass growth slowly resumed at $30^{\circ} \mathrm{C}$, reaching its normal rate after about $70 \mathrm{~min}$. At this time, the filaments also started to divide (Fig. 2b). Immediately after chloramphenicol removal, the large nucleoid-pole distances in the filaments decreased gradually (Fig. 2c), indicating that the DNA from the fused nucleoids moved back into the previously occupied cell ends. In view of the run-out DNA synthesis, which may be expected to occur during chloramphenicol treatment, it is remarkable that the individual chromosomes do not resegregate as independent entities, but that nucleoid regions, presumably containing two or more chromosome equivalents, resegregate together (however, see below). The mean number of nucleoid regions per filament increased only gradually, reaching a value of $3 \cdot 2$ after $75 \mathrm{~min}$ (Table 1) and of 4.0 after $120 \mathrm{~min}$ (not shown). This movement towards the cell poles occurred while mass growth had hardly resumed (see Fig. 2a). As we measured no increase in the mean length of the filaments (Table 1), we conclude that nucleoid resegregation can occur as soon as protein synthesis is reactivated, but is not dependent 
on a full recovery of the rate of mass growth or length increase.

\section{Division recovery in the filaments}

As indicated in Fig. 2(b), cell divisions started again after a delay of about $75 \mathrm{~min}$. In contrast to the ftsZ84(Ts) strain (Taschner et al., 1988), E. coli $p b p B$ has been shown to initiate constrictions during growth in glucose minimal medium at $42{ }^{\circ} \mathrm{C}$. These initial constrictions, at positions in the middle and at one-quarter and threequarters cell length, are clearly visible in the electron microscope (Taschner et al., 1988; Wientjes \& Nanninga, 1989). Although they are less evident in the combined phase-contrast and fluorescence images presented here (arrows in Fig. 1c), they become clearly visible as the constriction process resumes at $30^{\circ} \mathrm{C}$. At 75 min after chloramphenicol removal, $63 \%$ of the $E$. coli $p b p B$ filaments showed one or more deep constrictions. Although the first divisions often occurred at midcell, later divisions seemed to take place at the poles (Fig. 3b, c). However, quantification of deep constrictions showed that divisions took place with equal frequency either at midcell or at one-quarter and threequarter positions. Apparently, the division sites previously established during growth at $42{ }^{\circ} \mathrm{C}$ could be reactivated. In Table 1 the lengths of newborn cells, and of the nucleoids they contain, are indicated for 95, 105 and $115 \mathrm{~min}$ after chloramphenicol removal. These recovering cells have a mean size of $3 \cdot 5-3.8 \mu \mathrm{m}$. This is larger than the length of a newborn cell in the exponentially growing culture at $30^{\circ} \mathrm{C}(2 \cdot 0 \mu \mathrm{m}$; see also Taschner et al., 1988) or of the synchronized cells $(2.6 \mu \mathrm{m}$; Table 1$)$. The increased length reflects the resumed growth of the cell units, as defined by the previously established division sites, upon chloramphenicol removal.

In contrast, the mean length of the resegregated nucleoids $(1.16 \mu \mathrm{m}$; Table 1$)$ is smaller than in newborn cells $(1.26 \mu \mathrm{m}$; Table 1$)$. Although this could be ascribed to the segregation of nucleoids containing, after run-out DNA synthesis, a single chromosome equivalent (see Fig. 3c), such an interpretation needs confirmation by image cytometric quantification of the amount of DNA per individual nucleoid (to be reported elsewhere). In any case, these early constrictions could generate cells with asymmetrically localized nucleoids (Fig. 3c) and even DNA-less cells. The $9-22 \%$ of DNA-less cells observed until $115 \mathrm{~min}$ after chloramphenicol removal (Table 1) result from early division events in the recovering filaments and represent about $7 \%$ of the potential division sites present (assuming an average of three sites per filament). In view of this imbalance between resegregation and cell division, it is remarkable that no 'guillotine-like' constrictions (Niki et al., 1991) occurred at the position of a nucleoid. In the stationary phase, sampled after $16 \mathrm{~h}$ incubation at $30^{\circ} \mathrm{C}$, a homogeneous population of small cells was obtained with less than $1 \%$ of DNA-less cells (Table 1 ), indicating that DNA-less cells were only formed in the early stage of growth and division recovery, and that at later stages
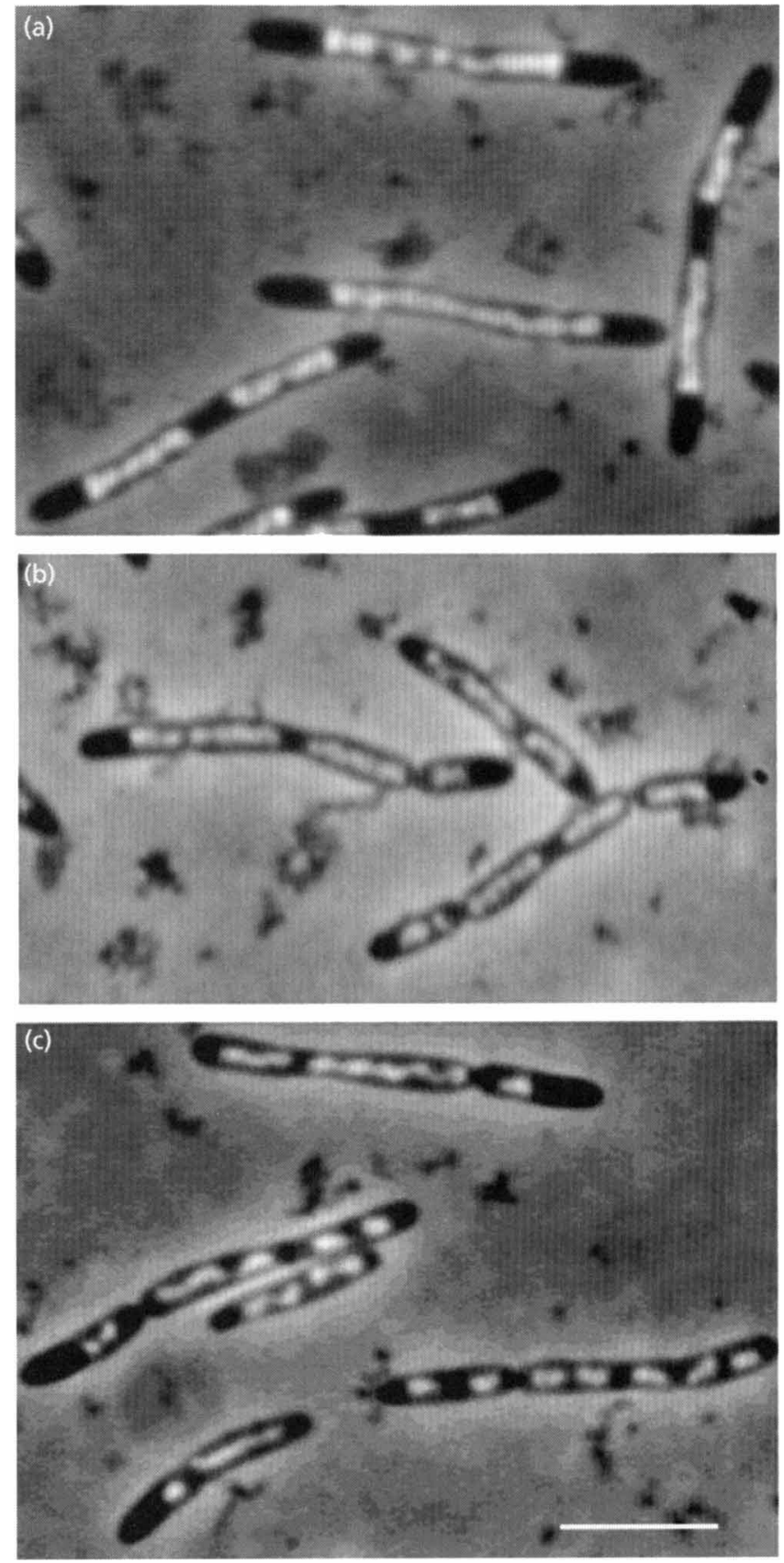

Fig. 3. Phase-contrast and fluorescence images during nucleoid resegregation and division recovery of $p b p B$ filaments. Compare with length measurements in Table 1. (a) 45 min after removal of chloramphenicol by filtration and growth resumption at $30^{\circ} \mathrm{C}$ (arrow 3 in Fig. 2c). (b) $75 \mathrm{~min}$ after removal of chloramphenicol and growth at $30^{\circ} \mathrm{C}$ (arrow 4 in Fig. 2c). Nucleoids have moved back into the previously occupied cell ends. (c) $115 \mathrm{~min}$ after chloramphenicol removal (arrow 5 in Fig. 2c). The first divisions have taken place. Note the asymmetric localization of nucleoids in cell ends that are being pinched off. Bar, $5 \mu \mathrm{m}$.

mostly normal cells were formed. In conclusion, all potential division sites in the filaments can be reused during recovery, but most divisions are postponed until the nucleoids have resegregated. Parallel experiments 

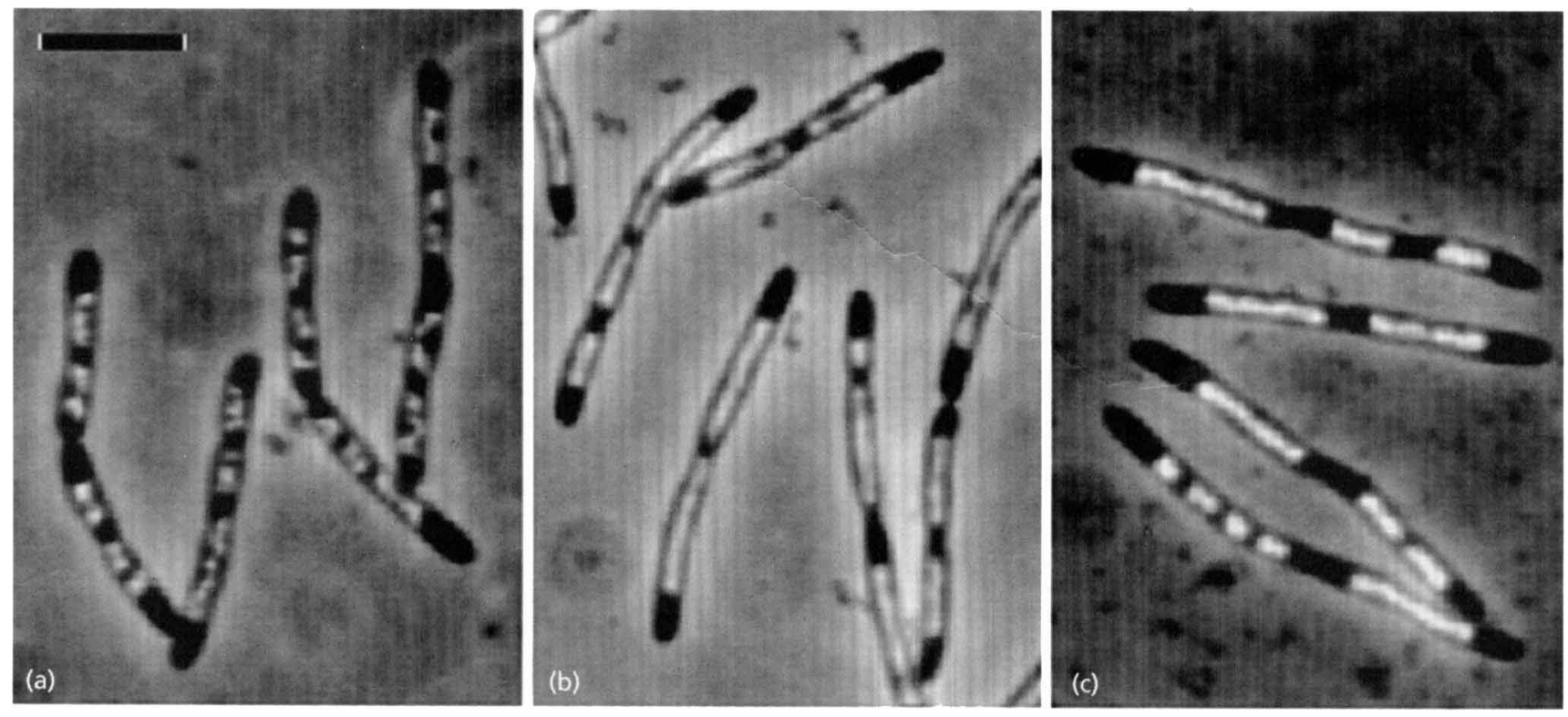

Fig. 4. Effect of protein synthesis inhibition on nucleoid morphology in $E$. coli pbp $B$ filaments grown for two mass

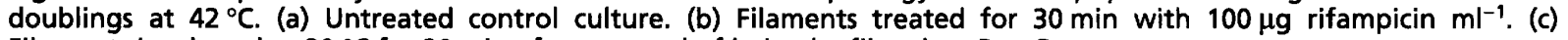
Filaments incubated at $30^{\circ} \mathrm{C}$ for $30 \mathrm{~min}$ after removal of lysine by filtration. Bar, $5 \mu \mathrm{m}$.

(results not shown) performed with an E. coliftsZ84(Ts) strain, showed a similar fusion and resegregation of nucleoids. However, division recovery after chloramphenicol removal took much longer $(175 \mathrm{~min})$. No DNA-less cells were formed in the ftsZ84 filaments, probably because nucleoids had more time to move into the DNA-free cell ends.

\section{Nucleoid fusion and compaction induced by other agents}

Treatment of E. coli $p b p B$ filaments (Fig. 4a) with rifampicin, or lysine starvation, induced nucleoid fusion, similar to that observed after treatment with chloramphenicol. However, after rifampicin treatment (Fig. 4b), the nucleoids retracted less far from the cell poles than after lysine starvation (Fig. 4c) or chloramphenicol treatment (Fig. 1b). Our results with rifampicin contradict the observation of Harrington \& Trun (1997) that rifampicin causes nucleoids to decondense. Nucleoid fusion by chloramphenicol was also observed in filamentous cells of Bacillus subtilis and in spherical E. coli $p b p A$ cells (results not shown). These observations suggest that nucleoid fusion represents a general phenomenon that occurs in different species and strains, and that can be ascribed to the loss of transcriptional and/or translational activity of the DNA.

\section{DISCUSSION}

We have used the phenomenon of nucleoid fusion caused by chloramphenicol treatment, first observed by Schaechter \& Laing (1961), to study the process of resegregation and recovery of division in $E$. coli filaments released from inhibition. The results demonstrate that during growth resumption, but before full recovery of the rate of cell elongation, the fused nucleoids are able to resegregate into the previously occupied cell ends. In an analysis of normal-sized cells recovering from chloramphenicol inhibition (Van Helvoort \& Woldringh, 1994), we could not confirm the observations of Hiraga et al. (1990) that daughter chromosomes move from midcell to one-quarter and three-quarter positions without elongation and we have contended that nucleoids do not move faster than the cell elongates. However, the present results clearly show that resegregating nucleoids can move faster than cell elongation in filaments.

\section{Transcription-mediated segregation}

It has been suggested that numerous interactions between the DNA, cytoplasm and plasma membrane pull the nucleoid into an extended or even lobular form (Daneo-Moore \& Higgins, 1972; Kleppe et al., 1979; Woldringh \& Nanninga, 1985). In accordance with this view, we have proposed that the shape of the nucleoid is the result of a balance between physical compaction forces (Murphy \& Zimmerman, 1995) and expansion through co-transcriptional and co-translational translocation of membrane proteins (Woldringh et al., 1995a ; see also Norris, 1995; Norris \& Madsen, 1995). The phenomenon of nucleoid fusion suggests that these interactions not only determine the shape of the nucleoid, but also play a role in DNA segregation (Fig. 5). In filaments, abolition of the interactions allows the physical compaction forces to push different nucleoids together into one region. We conclude that the growing cell needs an active driving force to segregate its DNA, both in filaments and during the normal cell cycle. We 
further hypothesize that this driving force results from the random expression of numerous genes encoding membrane proteins. By the formation of an mRNA/ ribosome/signal recognition particle/translocation complex, these genes form DNA loops indirectly attached to the plasma membrane (Lynch \& Wang, 1993; Luirink \& Dobberstein, 1994). Although individually transient, collectively these many DNA loops are able to expand and move the nucleoid in the growing cell. This expansion mechanism is thus an emergent property of many nonspecific genes occurring dispersed over the entire chromosome. We assume that this mechanism is sufficient to gradually separate the two daughter nucleoids if, after initiation of DNA replication at the unique origin, a displacement of the two daughter strands occurs. Such an initial displacement could be performed by a dedicated mechanism that pulls or pushes the newly replicated origin regions toward opposite cell ends. A polar localization of the origin and the involvement of specific partition proteins has been described for both B. subtilis (Webb et al., 1997) and Caulobacter crescentus (Mohl \& Gober, 1997). In E. coli, the 'motor protein' MukB has been suggested to play such a dedicated role in segregation (Hiraga, 1993). An initial displacement could also be mediated by the formation of a ribosome assembly compartment at rRNA genes occurring close to the origin (Woldringh \& Nanninga, 1985).

As schematically depicted in Fig. 5, we propose that once the origin regions (A and B in Fig. 5) have been separated along the cell's length axis, subsequent expression of membrane proteins on the daughter strand ( $\mathrm{a}$ in Fig. 5) belonging to origin A will pull the DNA to the membrane region on the side of that origin. This expansion mechanism is also suitable for the continuing segregation during multifork replication. To explain the outward movement of fused nucleoids as described here, we assume that the many DNA loops extending from the closely packed nucleoids are hampered in finding a location to insert their membrane proteins and are forced to attach to the vacated membrane at the ends of the filament, thereby pulling the DNA outward. At present we have no idea how many DNA loops are involved and what force they have to generate for nucleoid movement. Although the insertion of new membrane proteins will finally lead to a recovery of the rates of membrane extension and cell elongation, the expansion mechanism is at first not dependent on this elongation. During the normal cell cycle depicted in Fig. 5 , each set of loops belonging to one daughter strand will generate a zone of membrane growth causing length extension and nucleoid movement to go hand in hand.

\section{Resegregation after inhibition of DNA synthesis}

During resegregation in the filaments studied in this work, no indication was found of nucleoids being rapidly moved apart by a fixed distance (unit length) as suggested by Begg \& Donachie (1991). They based their conclusion on the observation that in fts $A$ filaments, only two spacings between the centres of nucleoids

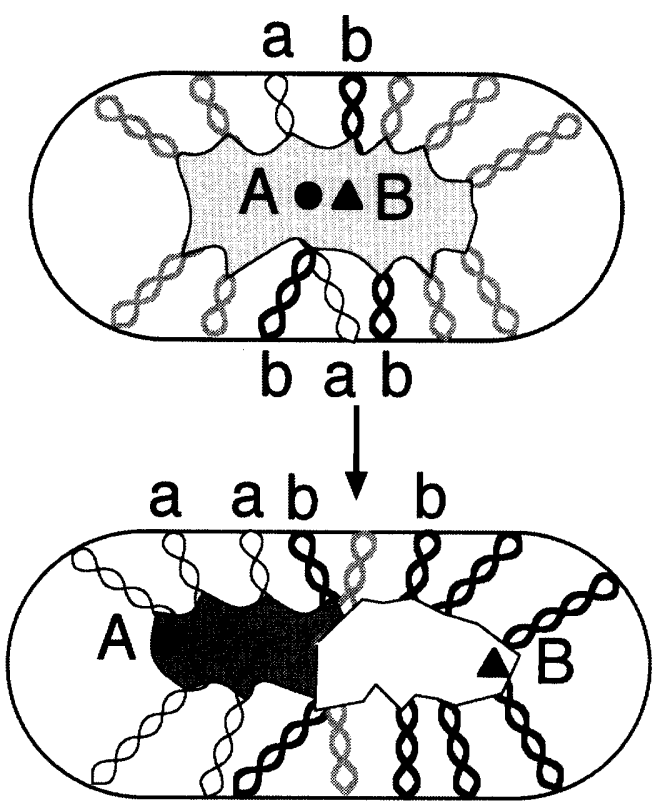

Fig. 5. Working model for transcription-mediated segregation. This model assumes (i) a dedicated mechanism for the initial displacement of the origins ( $A$ and $B$ ) and (ii) the expansion of the nucleoid by the transient attachment of DNA loops through co-transcriptional and co-translational translocation of membrane proteins forms two membrane-growth zones that cause cell elongation. Grey-coloured, supercoiled loops represent DNA from the unreplicated chromosome. Thin (a) and thick (b) supercoils represent loops belonging to newly replicated daughter strands with origin A and B, respectively. Because of the initial displacement (by a dedicated mechanism) of the A-origin to the left, the a-loops will, on average, attach to the membrane on the left side of the cell, thus pulling subsequently replicated DNA regions to that side. This segregation mechanism is also suitable for segregation during multifork replication: if, after reinitiation, the origins of each pair are moved apart along the cell's long axis, the subsequently replicated daughter strands will again be pulled towards them, now forming two pairs of membrane growth zones.

occur: either a small distance in the case of connected pairs (dumbell shapes) or twice that distance in the case of separated nucleoids. However, it was not realized at that time that chloramphenicol not only influences the shape, but also the positioning of nucleoids. Nevertheless, these authors did observe a gradual redispersal of DNA from a central area to the cell poles in E. coli fts $A$ thy $A$ filaments that had grown for a limited period in the absence of DNA replication. They concluded that the segregation mechanism fails when DNA synthesis is inhibited, contrary to the observation of continued movement of nucleoid regions in cells not treated with chloramphenicol (Woldringh et al., 1994).

A redistribution into DNA-free regions along the cell length has previously also been suggested to occur in a temperature-sensitive DNA mutant of $B$. subtilis (Mendelson, 1972), using autoradiographic detection of radioactively labelled DNA. Because mass growth declined after the temperature shift, nucleoid fusion could well have taken place in these filaments due to inhibition 
of protein synthesis. Upon shift back to the permissive temperature, nucleoid resegregation may have occurred, as suggested by the author. As expected after DNA synthesis inhibition, DNA-less cells were also formed (cf. Mulder \& Woldringh, 1989).

\section{Resegregation and division recovery}

The present analysis of division recovery in $p b p B$ filaments has a bearing on recent studies of dissolution and reformation of FtsZ rings in cell division mutants. In $p b p B$ filaments, continuation rather than initiation of cell constriction is inhibited, resulting in partial constrictions when cells are grown in glucose-minimal medium. This initiation has been proposed to be performed by a penicillin-insensitive peptidoglycansynthesizing mechanism (Nanninga, 1991), which includes the assembly of the FtsZ ring structure (Bi \& Lutkenhaus, 1991). It has been shown by immunofluorescence for different $f t s$ mutations such as $p b p B$ ( $f t s I$ ), fts A (Addinall et al., 1996; Addinall \& Lutkenhaus, 1996; Pogliano et al., 1997) and ftsW (Khattar et al., 1997), that FtsZ ring structures are formed and correctly spatially positioned in the mutants at restrictive temperatures. Although Pogliano et al. (1997) found that the function of PBP3 (FtsI) was required for the assembly of additional Fts $Z$ rings in filaments grown in rich medium, and Addinall et al. (1997) found that FtsZ does not return to sites that have a partial constriction, our results on $p b p B$ filaments grown in glucose-minimal medium show that eventually, all the constriction sites established at $42{ }^{\circ} \mathrm{C}$ do recover after shifting back to the permissive temperature. At present, it is not clear whether this division recovery is influenced or postponed by the resegregating nucleoids. According to the periseptal annulus model (Cook \& Rothfield, 1994) division sites are differentiated and positioned by an active mechanism that resides in the cell envelope. Upon shift back to the permissive temperature, the established sites might be expected to become reactivated independently of the resegregating nucleoids. It is remarkable, however, that apart from divisions leading to asymmetrically localized nucleoids or DNAless cells, no guillotine-like constrictions (Niki et al., 1991) at the site of a nucleoid were observed. This lends support to an inhibitory effect of the nucleoid, actively involved in transcription/translation, on the constriction process as proposed in the nucleoid occlusion model (Mulder \& Woldringh, 1989; Woldringh et al., 1991). Future experiments, in which both FtsZ ring assembly and the amount of DNA per individual nucleoid region are determined during growth recovery and during the normal cell cycle, should provide further insight into a possible role of (re)segregating DNA in signalling division.

\section{ACKNOWLEDGEMENTS}

We thank N. Nanninga for encouragement and reading of the manuscript, W. D. Donachie for critical remarks, and K. V. Rasmussen, I. Fishov, A. P. Van Gool and A. Zaritsky for stimulating discussions and suggestions. This work was supported by the Foundation of Life Sciences of the Dutch Organization of Scientific Research (NWO).

\section{REFERENCES}

Addinall, S. G. \& Lutkenhaus, J. (1996). FtsA is localized to the septum in an FtsZ-dependent manner. J Bacteriol 178, 7167-7172.

Addinall, S. G., Bi, E. \& Lutkenhaus, J. (1996). FtsZ ring formation in $\mathrm{fts}$ mutants. $J$ Bacteriol 178, 3877-3884.

Addinall, S. G., Cao, C. \& Lutkenhaus, J. (1997). Temperature shift experiments with an $f t s Z 84(T s)$ strain reveal rapid dynamics of Fts $Z$ localization and indicate that the $Z$ ring is required throughout septation and cannot reoccupy division sites once constriction has initiated. J Bacteriol 179, 4277-4284.

Åkerlund, T., Nordström, K. \& Bernander, R. (1995). Analysis of cell size and DNA content in exponentially growing and stationary-phase batch cultures of Escherichia coli. J Bacteriol $177,6791-6797$.

Begg, K. J. \& Donachie, W. D. (1991). Experiments on chromosome partitioning and positioning in Escherichia coli. New Biol 3, 475-486.

Bi, E. \& Lutkenhaus, J. (1991). FtsZ ring structure associated with division in Escherichia coli. Nature 354, 161-164.

Bremer, H. \& Churchward, G. (1977). Control of cyclic chromosome replication in Escherichia coli. Microbiol Rev 55, 459-475.

Cook, W. R. \& Rothfield, L. I. (1994). Early stages in development of the Escherichia coli cell-division site. Mol Microbiol 14, $485-495$.

Daneo-Moore, L. \& Higgins, M. L. (1972). Morphokinetic reaction of Streptococcus faecalis (ATCC 9790) cells to the specific inhibition of macromolecular synthesis: nucleoid condensation on the inhibition of protein synthesis. J Bacteriol 109, 1210-1220.

Donachie, W. D. (1993). The cell cycle of Escherichia coli. Annu Rev Microbiol 47, 199-230.

Harrington, E. W. \& Trun, N. J. (1997). Unfolding of the bacterial nucleoid both in vivo and in vitro as a result of exposure to camphor. J Bacteriol 179, 2435-2439.

Hiraga, S. (1993). Chromosome partition in Escherichia coli. Curr Opin Genet Dev 5, 789-801.

Hiraga, S., Ogura, T., Niki, H., Ichinose, C. \& Mori, H. (1990). Positioning of replicated chromosomes in Escherichia coli. J Bacteriol 172, 31-39.

Jaffé, A., D'Ari, R. \& Norris, V. (1986). SOS-independent coupling between DNA replication and cell division in Escherichia coli. J Bacteriol 165, 66-71.

Khattar, M. M., Addinall, S. G., Stedul, K. H., Boyle, D. S., Lutkenhaus, J. \& Donachie, W.D. (1997). Two polypeptide products of the Escherichia coli cell division gene fts $W$ and a possible role for FtsW in FtsZ function. J Bacteriol 179, 784-793.

Kleppe, K., Övrebö, S. \& Lossius, I. (1979). The bacterial nucleoid. $J$ Gen Microbiol 112, 1-13.

Luirink, J. \& Dobberstein, B. (1994). Mammalian and Escherichia coli signal recognition particles. Mol Microbiol 11, 9-13.

Lynch, A. S. \& Wang, J. C. (1993). Anchoring of DNA to the bacterial cytoplasmic membrane through cotranscriptional synthesis of polypeptides encoding membrane proteins for export: a mechanism of plasmid hypernegative supercoiling in mutants deficient in DNA topoisomerase I. J Bacteriol 175, 1645-1655.

Mendelson, N. H. (1972). Deoxyribonucleic acid distribution in 
Bacillus subtilis independent of cell elongation. $J$ Bacteriol 111, 156-162.

Mohl, D. A. \& Gober, J. W. (1997). Cell cycle-dependent polar localization of chromosome partitioning proteins in Caulobacter crescentus. Cell 88, 675-684.

Mulder, E. \& Woldringh, C. L. (1989). Actively replicating nucleoids influence the positioning of division sites in DNA-less cell forming filaments of Escherichia coli. J Bacteriol 171, 4303-4314.

Murphy, L. D. \& Zimmerman, S. B. (1995). Condensation and cohesion of $\lambda$ DNA in cell extracts and other media: implications for the structure and function of DNA in prokaryotes. Biophys Chem 57, 71-92.

Nanninga, N. (1991). Cell division and peptidoglycan assembly in Escherichia coli. Mol Microbiol 5, 791-795.

Niki, H., Jaffé, A., Imamura, R., Ogura, T. \& Hiraga, S. (1991). The new gene $m u k B$ codes for a $177 \mathrm{kDa}$ protein with coiled-coil domains involved in chromosome partitioning of E. coli. EMBO J 10, 183-193.

Norris, V. (1995). Hypothesis: chromosome separation in Escherichia coli involves autocatalytic gene expression, translation and membrane-domain formation. Mol Microbiol 16, 1051-1057.

Norris, V. \& Madsen, M. S. (1995). Autocatalytic gene expression occurs via transertion and membrane domain formation and underlies differentiation in bacteria: a model. $J$ Mol Biol 253, 739-748.

Pogliano, J., Pogliano, K., Weiss, D. S., Losick, R. \& Beckwith, J. (1997). Inactivation of FtsI inhibits constriction of the FtsZ cytokinetic ring and delays the assembly of FtsZ rings at potential division sites. Proc Natl Acad Sci USA 94, 559-564.

Schaechter, M. \& Laing, V. O. (1961). Direct observation of fusion of bacterial nuclei. J Bacteriol 81, 667-668.

Taschner, P. E. M., Huls, P. G., Pas, E. \& Woldringh, C. L. (1988). Division behavior and shape changes in isogenic fts $Z, f t s Q, f t s A$, $p b p B$ and $f t s E$ cell division mutants of Escherichia coli during temperature shift experiments. J Bacteriol 170, 1533-1540.

Van Helvoort, J. M. L. M. \& Woldringh, C. L. (1994). Nucleoid partitioning in Escherichia coli during steady-state growth and upon recovery from chloramphenicol treatment. Mol Microbiol 13, 577-583.

Van Helvoort, J. M. L. M., Kool, J. \& Woldringh, C. L. (1996). Chloramphenicol causes fusion of separated nucleoids in Escherichia coli $\mathrm{K}-12$ cells and filaments. J Bacteriol 178, 4289-4293.

Vischer, N. O. E., Huls, P. G. \& Woldringh, C. L. (1994). Objectimage: an interactive image analysis program using structured point collection. Binary 6, 160-166.

Webb, C. D., Teleman, A., Gordon, S., Straight, A., Belmont, A., Chi-Hong Lin, D., Grossman, A. D., Wright, A. \& Losick, R. (1997). Bipolar localization of the replication origin regions of chromosomes in vegetative and sporulating cells of B. subtilis. Cell 88, $667-674$.

Wheeler, R. T. \& Shapiro, L. (1997). Bacterial chromosome replication: is there a mitotic apparatus? Cell 88, 577-579.

Wientjes, F. B. \& Nanninga, N. (1989). Rate and topography of peptidoglycan synthesis during cell division in Escherichia coli: concept of a leading edge. J Bacteriol 171, 3412-3419.

Woldringh, C. L. \& Nanninga, N. (1985). Structure of nucleoid and cytoplasm in the intact cell, pp. 161-197. In Molecular Cytology of Escherichia coli. Edited by N. Nanninga. New York: Academic Press.

Woldringh, C. L., Mulder, E., Huls, P. G. \& Vischer, N. O. E. (1991). Toporegulation of bacterial division according to the nucleoid occlusion model. Res Microbiol 142, 309-320.

Woldringh, C. L., Zaritsky, A. \& Grover, N. B. (1994). Nucleoid partitioning and the division plane in Escherichia coli. J Bacteriol 176, 6030-6038.

Woldringh, C. L., Jensen, P. R. \& Westerhoff, H. V. (1995a). Structure and partitioning of bacterial DNA: determined by a balance of compaction and expansion forces? FEMS Microbiol Lett 131, 235-242.

Woldringh, C. L., Fluiter, K. \& Huls, P. G. (1995b). Production of senescent cells of Saccharomyces cerevisiae by centrifugal elutriation. Yeast 11, 361-369.

Received 12 September 1997; revised 16 December 1997; accepted 16 January 1998. 